\title{
AQUAPONIC CORNER
}

\section{Control of ectoparasitosis in carp (Cyprinus carpio) induced by Gyrodactylus elegans (Monogenea) with garlic (Allium sativum) and onion (Allium cepa) extracts}

\author{
Hijran Yavuzcan Yildiz, Suleyman Bekcan \\ Department of Fisheries and Aquaculture, Ankara University, Ankara, Turkey \\ E-mail:yavuzcan@ankara.edu.tr
}

\begin{abstract}
One of the constraints in fish disease management in aquaponic systems is related to undesired effects of chemicals on fish, plants and beneficial bacteria. Plant-derived compounds with nontoxic features to fish, plants, and microflora provide an alternative treatment strategy against the harmful pathogens in the aquaponic system. The present study assessed the antiparasitic activity of garlic (Allium sativum) and onion (A. cepa) extracts against Gyrodactylus elegans (Monogenea) in vivo and in vitro, and physiological stress responses in carp, Cyprinus carpio, treated with these extracts in an aquaponics system. Garlic and onion extracts exhibited in vitro antiparasitic activity against $G$. elegans. The mean survival time of $G$. elegans in vitro ranged from $30 \mathrm{sec}$ to $6 \mathrm{~min}$ depending on the concentration and exposure time both for garlic and onion extracts. For garlic extract $\mathrm{EC}_{50}$ (median effective concentration) was $8.37 \pm 4.75 \mathrm{mg} / \mathrm{mL}$ in $3 \mathrm{~min}$ exposure and for onion extract $4.72 \pm 7.10 \mathrm{mg} / \mathrm{mL}$. These concentrations were in vivo tested in carp heavily infected with G. elegans as a single application for 3 min. In vivo treatment of carp with garlic and onion extracts reduced $G$. elegans found on the skin by $14.4 \%$ and $19.8 \%$, respectively. In both treatment groups, the physiological stress response of carp was mild based on the alterations in the secondary stress indicators (hematocrit, plasma glucose, and lactate). The stress indicators of carp returned to normal levels after an hour recovery in freshwater. The antiparasitic potential of onion and garlic extracts may be considered as an alternative treatment to reduce Monogenean infections in aquaponic systems.
\end{abstract}

Keywords - aquaponics, ectoparasite, Gyrodactylus elegans, garlic, onion

\section{INTRODUCTION}

Aquaponic systems integrate recirculating aquaculture (RAS) with hydroponics. The complexity of aquaponic systems entails the consideration of sustainability, including economical, technical and social aspects (König et al. 2016). The management of fish diseases is one of the challenges in aquaponic systems. Parasites particularly create serious health risks for fish and limit productivity in aquaponic systems (Goddek et al. 2015). Monogenean parasites display a single-host life cycle (Buchmann and Lindenstrøm 2012; Hutson et al. 2018) and have the ability to infect the skin and gills of marine and freshwater fish. Species of the genus
Gyrodactylus generally attach to the skin of freshwater fishes. Gyrodactylus spp. are characterized by being viviparous with high reproductive capacity (Stoskopf 1993). The pathogenicity of Gyrodactylus spp. depends on several environmental factors such as water temperature, $\mathrm{pH}$ and nutrient concentrations (Bakke et al. 2002). Sub-optimal water quality and other stressors in aquaponics can predispose fish to an invasion of Monogenean parasites because it is usually not possible to ensure optimal production parameters simultaneously for fish and plants.

As it is difficult to eradicate Monogeneans from fish skin or gills various externally applied agents are used to control 
Monogenean species. The application of agents, mainly chemicals involves some questions on environmental contamination and human health concerns (Fridman et al. 2014). The antiparasitic chemicals have an impact on the environment in terms of lethal or sub-lethal effects on nontarget organisms. Treatments with chemicals may lead to accumulation in fish tissue and disruption of the natural microflora of the fish (Wunderlich et al. 2017). Specifically, in aquaponics, the parasite treatments may have harmful effects on the rest of the system, including the biofilter, nitrification biofilm, and plants, causing limitation of disease treatment (Goddek et al. 2015; Yildiz et al. 2017).

Thus, in recent years natural plant products are taken into consideration to control parasites in aquaculture to eliminate the problems due to chemical use. In aquaponics, one effective treatment option against the ectoparasite invasions is immersion or bath with plant-derived compounds due to the complexity of the system. The effects of extracts, essential oils and bioactive metabolites from diverse terrestrial and aquatic plants on fish parasites have been studied as an alternative treatment against different parasite species of fish (Wang et al. 2011; Wu et al. 2011; Lu et al. 2012; Ramudu and Dash 2013; Valladao et al. 2015; Tavares-Dias 2018). With rich bioactive compounds, garlic (Allium sativum) and onion ( $A$. серa) have been used for therapeutic purposes since ancient times (Anthony et al. 2005; Lanzotti 2012). Hyun Kim et al. (2018) studied the effects of garlic on Cryptocaryon irritans (Ciliates) found on guppies (Poecilia reticulata) in vitro and in vivo, reporting a failure to cure. Fridman et al. (2014) revealed that the treatment of Gyrodactylus turnbulli on guppy skin with garlic extract (bath at a concentration of 7.5 and $12.5 \mathrm{~mL}$ for $1 \mathrm{~h}$ ) resulted in the detachment of parasite and death, indicating reduced parasite prevalence. Apart from external applications, the administration of plants or plant-derived substances in the feed was evaluated for their anti-parasitic activity. Militz et al. (2013) disclosed that garlic extract as a supplement to the diet can prevent Neobenedenia sp. (Monogenea) infection in farmed barramundi (Lates calcarifer). In line with this study, Martins et al (2002) reported that garlic powder in the diet of cultivated pacu (Piaractus mesopotamicu) resulted in a significant reduction of Anacanthorus penilabiatus (Monogenea) in the gills. On the other hand, the treatment of fish with various substances, even herbal ones may be a source of stress, impairing welfare. The welfare status of fish, as measured by the indices of stress can be unveiling (Roque et al. 2010). The secondary stress response can be expressed by the alteration in blood profile as the physiological effects of factors released in the primary response phase affect the metabolism (Kjartansson et al. 1988; Yildiz and Pulatsu 1999). Stress induces changes in energy metabolism and blood cells as reflected by the changes in baseline stress indicators including plasma glucose, lactate and hematocrit levels (Ellis et al 2012).

The present study tested the possible use of in vitro antiparasitic activity of garlic and onion extracts against Gyrodactylus elegans (Monogenean) recovered from carp (Cyprinus carpio) skin. In vivo the effects of immersion treatments with garlic and onion extracts on parasite reduction in skin and physiological stress response of carp (Cyprinus carpio) were evaluated.

\section{MATERIAL AND METHODS}

\section{Fish and parasites}

Carp were obtained from the one-loop aquaponic systems producing carp and mint (Mentha spp.) in Ankara University, Department of Fisheries and Aquaculture. One-loop aquaponic system characteristics were explained in detail by Goddek et al. (2009). The stocking ratio of fish was $35 \mathrm{~kg} / \mathrm{m}^{3}$ in the fiberglass fish tanks $(80 \times 60 \times 50 \mathrm{~cm})$. Water temperature was $20-22{ }^{\circ} \mathrm{C}$, dissolved oxygen was $5.50-5.97 \mathrm{mg} / \mathrm{L}$ and $\mathrm{pH}$ was 6. Fish were fed with commercial rainbow trout feed (containing $45 \%$ raw protein) with $2 \%$ body weight. During routine fish health control in the aquaponics system, monogenean skin parasites on the skin were detected. The parasites were identified as G. elegans (Paperna 1996; Akmirza and Yardimci 2014). The scrapped mucosa samples were weighed before placement on the slides and counted for in vitro parasite survival tests.

Fish management and experimental protocol were approved by the ethics committee of the Ankara University with the reference number of 2019-7-72. No fish were killed while carrying out the experiments.

\section{Extract preparation}

Garlic cloves and onion were obtained from the local market, Ankara, Turkey. Garlic or onion was crushed and blended in a kitchen vortex. The blended material was weighed and 10 $\mathrm{mg}$ of them were diluted in $20 \mathrm{~mL}$ distilled water (stock solution) and vigorously mixed. This extract was freshly prepared before use and used as a stock solution.

\section{In vitro assay}

The effects of garlic and onion extract on in vitro parasite survival were tested. The exposure of parasite was carried out by dropping the garlic or onion extracts to the slides. Five concentrations of garlic or onion $(250,125,100,50$ and 10 $\mathrm{mg} / \mathrm{mL}$ ) were tested. Different solutions from the main stock solution were prepared for each test concentration. The motility and contraction of parasites were continuously observed under a microscope and the time to death was noted. Non-motile parasites that did not respond to a touch by a needle were considered dead. The death time intervals were specified as 10-30, 30-60, 60-90 seconds and 1.5-2, 2-3, 3-4 and 4-6 minutes. Three replicates were used per concentration and each replicate contained 4 parasites. Time to death was used to determine the median effective concentration (EC50) using a Probit analysis with a maximum likelihood regression algorithm.

\section{In vivo assays}

A total of 45 carp weighing 100-150 g infested with $G$. elegans were selected from the one-loop aquaponics system for immersion treatments and physiological stress tests. 


\section{Immersion treatment}

In vivo garlic and onion extract concentrations were chosen based on the minimum $\mathrm{EC}_{50}$ value $\left(\mathrm{EC}_{50}=8.37 \mathrm{mg} / \mathrm{mL}\right.$ for garlic and $4.72 \mathrm{mg} / \mathrm{mL}$ for onion) of garlic and onion extracts on fish. The carp used for the experiment were randomly divided into 5 treatment groups of 3 fish each and set up to different treatments as given below:

Group I: Treated with a single dose of garlic extract $\left(\mathrm{EC}_{50}=8.37 \mathrm{mg} / \mathrm{mL}\right)$ for $3 \mathrm{~min}$

Group II: Treated with a single dose of garlic extract $\left(\mathrm{EC}_{50}=8.37 \mathrm{mg} / \mathrm{mL}\right)$ for $3 \mathrm{~min}$ followed by $1 \mathrm{~h}$ recovery in freshwater

Group III: Treated with a single dose of onion extract $\left(\mathrm{EC}_{50}=4.72 \mathrm{mg} / \mathrm{mL}\right)$ for $3 \mathrm{~min}$

Group IV: Treated with a single dose of onion extract $\left(\mathrm{EC}_{50}=4.72 \mathrm{mg} / \mathrm{mL}\right)$ for $3 \mathrm{~min}$ followed by $1 \mathrm{~h}$ recovery in freshwater

Group V: Untreated control.

The treatments with garlic and onion extracts were performed in a 20 -L plastic pot containing $5 \mathrm{~L}$ of solutions with extracts and three infected carp. All treatment and control groups were conducted in triplicate. After the treatments, each fish was sampled for blood analysis.

\section{Blood analysis}

Blood samples were taken as soon as exposure of carp to garlic or onion extract and subsequently after $1 \mathrm{~h}$ (recovery in freshwater). Control fish were handled in the same manner. Fish were slightly anesthetized in a clove oil solution (5 $\mathrm{mg} / \mathrm{L}$ ) for $5 \mathrm{~min}$ before blood sampling. Blood samples were taken by heparinized syringes from the hearth. Hematocrit was measured immediately after blood sampling. Plasma was obtained by breaking the capillary hematocrit tubes after measurements. Plasma was stored at $-18 \mathrm{C}$ until further analysis. Plasma glucose and lactate were measured spectrophotometrically using commercial kits (Cayman Chemicals, USA) with a Shimadzu UV-1210V spectrophotometer according to the instructions of the manufacturer.

\section{In vivo antiparasitic efficacy assay}

The anthelmintic activities of garlic and onion extracts were assessed following to blood collection. After blood sampling, skin mucus of carp in all treatments and control groups were sampled. The scrapped mucus samples $(0.05 \mathrm{~g})$ were placed on glass slides, and the numbers of alive parasites in the mucus were counted under a light microscope (Nikon Type $120)$ at $25 \AA \sim 10$ magnification. The antiparasitic efficacy of each treatment and the control group were calculated according to the following formula (Wang et al. 2008):

Antiparasitic efficacy $=\mathrm{A}-\mathrm{B} / \mathrm{A} \times 100$

A: The mean number of parasites in carp mucus in the treatment group

$\mathrm{B}$ : The mean number of parasites in carp mucus in the control group.

\section{Statistics}

Probit analysis (Finney, 1971) was used for the calculation of the EC50 at the $95 \%$ confidence level (95\% CL) with NCSS statistical software. Statistical analysis was performed using one-way ANOVA followed by Tukey's post hoc test. Differences were considered significant at $\mathrm{p}<0.05$.

\section{RESULTS}

\section{In vitro parasite survival}

In vitro mortality of $G$. elegans varied by both the concentrations and exposure time of garlic and onion extracts, $p<0.05\left(\mathrm{~F}_{2,31}=5.08\right.$ for garlic experiment $)$ and $\mathrm{F}_{2,31}=20.37$ for onion experiment). EC50 values of garlic and onion extracts for G.elegans changed by the exposure time (Table 1). For $G$. elegans garlic extract was found to be most effective with EC50 of $8.37 \pm 4.75 \mathrm{mg} / \mathrm{mL}$ and onion extract with EC50 of $4.72 \pm 7.10 \mathrm{mg} / \mathrm{mL}$. In vitro cumulative mortality of $G$. elegans exposed to garlic extracts were $100 \%$ in 6 min for the concentrations tested except the concentration of $10 \mathrm{mg} / \mathrm{ml}$ (Figure 1). Cumulative mortality for onion extracts showed a similar pattern to garlic exposure (Figure 2).

Table 1. In vitro EC50 of garlic (A. sativum) and onion $(A$. cepa) extracts to Gyrodactylus elegans $(\mathrm{N}=24$ for each test concentration).

\begin{tabular}{|c|c|c|c|c|c|}
\hline \multirow[b]{2}{*}{$\mathrm{EC}_{50}$} & \multicolumn{5}{|c|}{ Exposure time } \\
\hline & $\begin{array}{c}10-30 \\
\text { sec }\end{array}$ & $\begin{array}{c}30-60 \\
\text { sec }\end{array}$ & $\begin{array}{c}1-1.5 \\
\min \end{array}$ & $\begin{array}{c}1.5-2 \\
\min \end{array}$ & $\begin{array}{l}2-3 \\
\min \end{array}$ \\
\hline $\begin{array}{l}\text { Garlic } \\
\mathrm{mg} / \mathrm{mL}\end{array}$ & $\begin{array}{l}200.96 \\
\pm 52.16\end{array}$ & $\begin{array}{c}67.45 \\
\pm 13.98\end{array}$ & $\begin{array}{l}20.09 \\
\pm 5.37\end{array}$ & $\begin{array}{l}16.85 \\
\pm 5.18\end{array}$ & $\begin{array}{c}8.37 \\
\pm 4.75\end{array}$ \\
\hline $\begin{array}{l}\text { Onion } \\
\mathrm{mg} / \mathrm{mL}\end{array}$ & - & $\begin{array}{c}6861.26 \\
\pm 26.76\end{array}$ & $\begin{array}{c}78.20 \\
\pm 28.57\end{array}$ & $\begin{array}{c}58.80 \\
\pm 20.65\end{array}$ & $\begin{array}{c}4.72 \\
\pm 7.10\end{array}$ \\
\hline
\end{tabular}

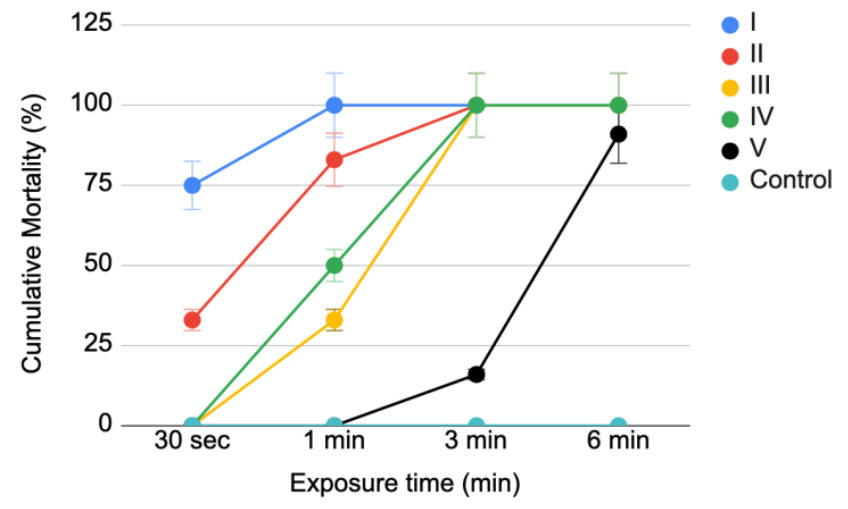

Figure 1. Cumulative mortality of Gyrodactylus elegans (Monogenean) exposed to garlic (A. sativum) extract in vitro. Concentrations (mg/mL) I-250; II-125; III-100; IV-50; V-10. Control: no extract exposure.

\section{Behavioral response}

The behavioral stress response in fish was apparent during the $3 \mathrm{~min}$ exposure of garlic at a concentration of $8.37 \mathrm{mg} / \mathrm{mL}$ or 
onion at a concentration of $4.72 \mathrm{mg} / \mathrm{mL}$ extract. Carp exhibited abnormal behavior with slight tremors.

\section{Physiological stress response}

Mean values of physiological stress parameters of carp exposed to garlic extract at a concentration of $8.37 \mathrm{mg} / \mathrm{mL}$ and onion $4.72 \mathrm{mg} / \mathrm{mL}$ for 3 minutes differed from control (Table 2).

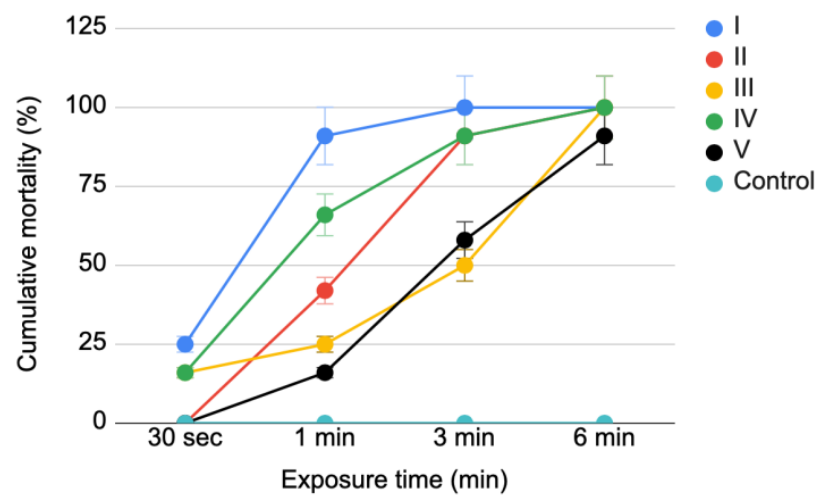

Figure 2. Cumulative mortality of $G$. elegans (Monogenean) exposed to different concentrations of onion (A. cepa) extract. Concentrations (mg/mL): I-250; II-125; III-100; IV-50; V10). Control: no extract exposure.

Table 2. Stress indicators of carp (C. carpio) exposed to i) garlic $(8.37 \mathrm{mg} / \mathrm{mL})$ or onion $(4.72 \mathrm{mg} / \mathrm{mL})$ extract for $3 \mathrm{~min}$, ii) garlic or onion extract followed by $1 \mathrm{~h}$ in freshwater (recovery) and iii) freshwater for $3 \mathrm{~min}$ (control).

\begin{tabular}{|l|c|c|c|}
\hline \multirow{2}{*}{$\begin{array}{l}\text { Garlic } \\
\text { Onion } \\
\text { Exposure }\end{array}$} & $\begin{array}{c}\text { Hematocrit } \\
(\%)\end{array}$ & $\begin{array}{c}\text { Plasma } \\
\text { Glucose } \\
(\mathrm{mg} / \mathrm{dL})\end{array}$ & $\begin{array}{c}\text { Plasma } \\
\text { Lactate } \\
(\mathrm{mg} / \mathrm{dL})\end{array}$ \\
\cline { 2 - 4 } & & $88.72 \pm 1.98^{\mathrm{b}}$ & $17.57 \pm 0.71^{\mathrm{ab}}$ \\
\hline Garlic & $40.41 \pm 2.93^{\mathrm{b}^{*}}$ & & $11.97 \pm 1.90^{\mathrm{a}}$ \\
\hline Recovery & $34.42 \pm 1.62^{\mathrm{a}}$ & $79.01 \pm 3.26^{\mathrm{a}}$ & \\
\hline & & $82.74 \pm 3.24^{\mathrm{b}}$ & $15.86 \pm 0.95^{\mathrm{ab}}$ \\
\hline Onion & $30.5 \pm 1.31^{\mathrm{a}}$ & $76.01 \pm 3.23^{\mathrm{a}}$ & $10.25 \pm 0.96^{\mathrm{a}}$ \\
\hline Recovery & $33.58 \pm 1.37^{\mathrm{a}}$ & & \\
\hline & & & \\
\hline Control & $36 \pm 2.08^{\mathrm{a}}$ & $78.35 \pm 3.95^{\mathrm{a}}$ & $9.31 \pm 0.34^{\mathrm{a}}$ \\
\hline
\end{tabular}

*Means ( $\mathrm{N}=9$ fish for each group) in a column with different superscripts are significantly different $(\mathrm{p}<0.05)$.

Hematocrit values were significantly elevated after treatment with garlic extract $(p<0.05)$ and declined to control levels following $1 \mathrm{~h}$ recovery in freshwater. Treatment with onion extract did not affect the hematocrit values $(\mathrm{p}>0.05)$. Plasma glucose values increased after treatment with garlic or onion extract $(\mathrm{p}<0.05)$ however, plasma glucose returned to control values after $1 \mathrm{~h}$ recovery. Plasma lactate levels of carp treated with garlic or onion extracts slightly differed from control values $(p<0.05)$. Plasma lactate levels decreased to control levels in $1 \mathrm{~h}$ recovery.

\section{In vivo antiparasitic efficacy}

In vivo G. elegans found on the skin of carp were significantly decreased by garlic or onion exposure $(\mathrm{p}<0.05)$. Garlic and onion extracts reduced $G$. elegans on the skin $14.40 \%$ and $19.79 \%$, respectively. The mean intensity of $G$. elegans in the mucus of carp $(0.05 \mathrm{~g})$ was $15.16 \pm 0.56$ before treatment and decreased to $12.83 \pm 1.36$ in garlic-treated and $12.0 \pm 1.2$ in the onion-treated group (Figure 3 ).

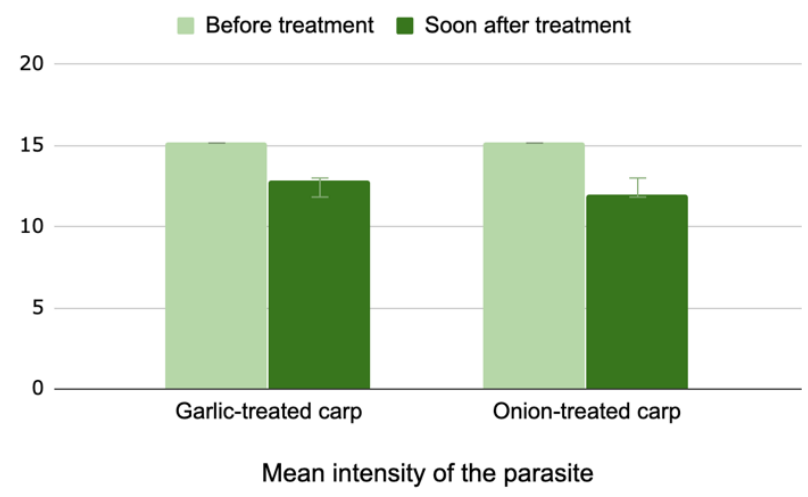

Figure 3. Reduction in mean intensity of $G$. elegans after 3 min exposure of carp to garlic and onion extracts.

\section{DISCUSSION}

Many plants and plant-derived compounds exert favorable effects to eradicate the disease agents with eliminating negative effects of synthetic chemical pharmaceuticals (Buchmann et al. 2003; Wu et al. 2011; Fridman et al. 2014; Wunderlich et al. 2017; Tavares-Dias 2018). The sensitivity of the plants against the diverse disease agents varies by the characteristics of the plant, indicating the need for more specific research (Trasvino Moreno et al. 2017; Hyun Kim et al. 2018; Tavares-Dias 2018). Various treatment effects of garlic on some Monogeneans have been studied in various fish species (Fridman et al. 2014; Schelkle et al. 2017) however, the studies on onion effects in fish parasites are relatively scarce (Yildiz et al. 2019). This study provides new information on the antiparasitic activity of onion against $G$. elegans (Monogenea).

In the present study, garlic and onion were evaluated for their antiparasitic activity against $G$. elegans found on the mucus of carp. Garlic and onion produce polar and apolar bioactive substances showing pharmacological effects such as cytotoxicity, antispasmodic and antifungal properties (Lanzotti 2012). Antiparasitic properties of main active compounds obtained from onion and garlic towards various parasite species have been reported (Corzo-Martínez et al. 2007). In the in vitro test, garlic and onion showed anthelmintic activity against $G$. elegans (Monogenean) from the skin of $C$. carpio depending on the concentration and duration. The finding of dose-dependent killing activity of garlic against Monogeneans in this study is in agreement with previous research on different fish and parasite species by Buchman et al. 2003; Fridman et al. 2014; Millitz et al. 2013; Soares et al. 2017; Hyun Kim et al. 2018; Yildiz et al. 2019. 
Considering EC50 values of garlic and onion extracts, the most effective concentration for garlic was $8.37 \pm 4.75 \mathrm{mg} / \mathrm{mL}$ $3 \mathrm{~min}$ and for onion $4.72 \pm 7.10 \mathrm{mg} / \mathrm{mL} 3 \mathrm{~min}$, revealing that onion was more effective against $G$. elegans than garlic. In our tests, in general, the survival time of $G$. elegans ranged from $1 \mathrm{~min}$ to $6 \mathrm{~min}$ in garlic-treated or onion-treated parasites. The findings of survival time ranges are similar to those reported in the previous study of Schelkle et al. (2013). However, Trasvino Moreno et al. (2017) has reported that the survival time of Neobenedenia sp. (Monogenea) exposed to garlic (dilution 1:10) was $7.6 \mathrm{~h}$ and $8 \mathrm{~h}$ for onion (dilution 1:10). The antiparasitic activity of garlic and garlic based material has been shown for a Ciliate, Cryptocaryon irritans in vitro however, in vivo tests with guppy, Poecilia reticulata infected with $C$. irritans were a failure to remove $C$. irritans (Hyun Kim et al. 2018). Garlic as the feed supplement decreased Neobenedenia sp. in barramundi, Lates calcarifer (Militz et al. 2013). The elimination of trichodinosis and gyrodactylosis from Nile tilapia, Oreochromis niloticus at a ratio of $68 \%$ has been reported by Abd El-Galil and Abdelhadid (2012). The intensity of G. elegans decreased by $14.40 \%$ in garlic-treated and $19.79 \%$ in onion-treated carp in the present study, showing lower efficacy levels than previous studies. Fridman et al (2014) reported that the prevalence of G. turnbulli decreased from $80 \%$ to $12.3 \%$ after bathing of infected guppy with garlic extract in the concentration of 7.5 $\mathrm{mL} / \mathrm{L}$ for $1 \mathrm{~h}$. Schelkle et al. (2013) revealed that garlic in the minced and granule forms reduced G.turnbulli by 66 and $75 \%$ after 3 subsequent applications and even 99\% efficiency in Chinese freeze-dried garlic and allyl disulfide after a single treatment. Lower values of the reduction in parasite intensity here may be related with form of the garlic or onion used and the single application. Antiparasitic activity of the plants tested in the present study was higher in vitro tests than invivo treatments. In vivo experiments were not with the similar results of in vitro tests as assessed by EC50. This can be explained by the penetration ability of monogeneans under scales as stated by Trujillo-González et al. (2015) or embedding into skin mucus. Fish epithelium can block the contact of allicin with the parasite, resulting in a decrease in efficacy (Hyun Kim et al. 2018). The repeated immersions may be necessary to increase the efficacy of the treatment to increase the probability of the contacts between parasite and the effective agents of garlic or onion. Unless the main active compounds of the plant such as allicin can activate apoptosis with reaching the parasite or disrupt the essential enzyme system in the parasite the efficacy of the immersions would not be high (Gruhlke et al. 2010).

Treatment of carp with garlic at the concentration of 8.37 $\mathrm{mg} / \mathrm{mL}$ for $3 \mathrm{~min}$ or onion at the concentration of $4.72 \mathrm{mg} / \mathrm{mL}$ for $3 \mathrm{~min}$ caused slight changes of the parameters tested in general. Plasma glucose and lactate are reliable indicators of stress in fish as the changes in carbohydrate mechanism may occur under stress as reflected by higher levels of glycemia and plasma lactate (Pickering et al. 1982; Roque et al. 2010). Plasma glucose as an indicator of stress response increased after the treatments with garlic or onion in the present study. This can be explained by a fast response activated by the sympatho-chromaffin axis to provide glucose supply to critical tissues to overcome the stress (Balasch and Tort
2019). In short-term acute stress response, it is expected higher values of plasma glucose, exceeding $200 \mathrm{mg} / \mathrm{mL}$ (Yildiz and Pulatsu 1999). Plasma glucose values of garlictreated or onion-treated carp did not show extremely high values and returned to control values after $1 \mathrm{~h}$ recovery. Plasma lactate values were similar to the control. Hematocrit values can be higher in stressful conditions to increase oxygen to the organs in response to higher metabolic demand (Cnaani et al. 2004). In this study, treatment with onion did not have any effect on hematocrit. The increase of hematocrit in garlic-treated carp was transient as hematocrit level returned to normal level after $1 \mathrm{~h}$. In the overall evaluation of physiological response to the treatments with garlic and onion, it can be concluded that acute stress response due to the treatments with garlic or onion extracts was not clear as the variations in stress parameters tested here showed slight changes and returned to control level following $1 \mathrm{~h}$ recovery. Fish exhibited abnormal behavior in immersion treatment with garlic or onion, indicating behavioral stress response. Fish survival was not affected by garlic and onion treatment and the aquaponic system was operated without any problem. Although the efficacy of the garlic and onion treatment was low against the parasites the intensity of the parasites did not increase and the fish did not die due to parasites.

\section{CONCLUSIONS}

Parasitic diseases can be devastating to fish in an aquaponic system. Due to the complexity of the aquaponic system with the plant, fish and bacteria immersion or bath with non-toxic plant-derived substances may provide an alternative solution against pathogens. Garlic and onion showed antiparasitic activity against Gyrodactylidae (Monogenea) to some extent. In vitro antiparasitic activity of garlic and onion were dosedependent to G.elegans. Based on EC50 values found in in vitro tests and subsequent in vivo tests, onion was more effective than garlic against $G$. elegans. In vivo application of garlic or onion with short term immersion resulted in low efficacy to $G$. elegans infection in carp, indicating the necessity of further investigations for more efficient forms of treatments in fish. The variations in the stress markers of carp exposed to garlic or onion may be attributed to mild stress response. The normal levels of hematocrit, plasma glucose and lactate after recovery in freshwater confirm the temporary stress effect of treatments with garlic or onion extracts. Garlic and onion can be considered as constituting antiparasitic potential to Monogeneans in fish despite their low efficiency. It is noteworthy that the use of garlic or onion to reduce parasite intensity in aquaponic systems is coherent for the context of eco-efficient aquaponic food production as the garlic and onion are non-toxic to human.

\section{ACKNOWLEDGMENTS}

The authors would like to acknowledge the contribution of the COST Action FA1305 (EU Aquaponics Hub). The authors would like to thank two anonymous reviewers for reading the manuscript critically and for their useful feedback and observations that have helped to improve this paper considerably. 


\section{REFERENCES}

Abd El-Galil, M. A. A, and Aboelhadid, S.M. 2012. Trials for the control of trichodinosis and gyrodactylosis in hatchery reared Oreochromis niloticus fries by using garlic. Veterinary Parasitology 185(2-4), 57-63.

DOI: $10.1016 /$ j.vetpar.2011.10.035

Akmirza._A, and Yardımc1, R.E. 2014. Fish parasites of Sakarya River, Turkey. Journal of Academic Documents for Fisheries and Aquaculture 1, 23-29.

Anthony, J. P., Fyfe, L., and Smith, H. 2005. Plant active components - A resource for antiparasitic agents? Trends in Parasitology 21(10), 462-468.

DOI: $10.1016 /$ j.pt.2005.08.004

Bakke, T.A., Harris, P.D. and Cable, J. 2002. Host specificity dynamics: observations on gyrodactylid monogeneans. International Journal for Parasitology 32, 281-308.

DOI: 10.1016/s0020-7519(01)00331-9

Balasch, J. C, and Tort, L. 2019. Netting the Stress Responses in Fish. Frontiers in Endocrinology 10, 1-12.

DOI: $10.3389 /$ fendo.2019.00062

Buchmann K, Lindenstrøm, T. 2002 Interactions between monogenean parasites and their fish hosts International Journal for Parasitology 32, 309-319.

DOI: 10.1016/s0020-7519(01)00332-0

Buchmann, K., Jensen, P.B. and Kruse, K.D. 2003. Effects of Sodium Percarbonate and Garlic Extract on Ichthyophthirius multifiliis Theronts and Tomocysts: In Vitro Experiments. North American Journal of Aquaculture 65(1), 21-24. DOI:10.1577/15488454(2003)065<0021:EOSPAG > 2.0.CO; $\underline{2}$

Cnaani, A., Tinman, S., Avidar Yaacov, R.M., Hulata, G. 2004. Comparative study of biochemical parameters in response to stress in Oreochromis niloticus, O. mossambicus and two strains of O. niloticus. Aquaculture Research 35, 1434-1440.

DOI: $10.1111 / \mathrm{j} .1365-2109.2004 .01167 . \mathrm{x}$

Corzo-Martínez, M., Corzo,N. and Villamiel, M. 2007. Biological properties of onions and garlic. Trends in Food Science and Technology 18(12), 609-625.

DOI: $\underline{10.1016 / \mathrm{j} . \text { tifs.2007.07.011 }}$

Ellis, T., Yildiz, H.Y., López-Olmeda, J., Spedicato, M.T., Tort, L., Øverli, Ø., Martins, C.L. 2012. Cortisol and finfish welfare. Fish Physiology and Biochemistry Feb;38(1), 16388. Epub 2011 Nov 24.

DOI: $10.1007 / \mathrm{s} 10695-011-9568-\mathrm{y}$
Finney, D.J. 1971. Probit Analysis. 3rd Edition. Cambridge University Press. 333p.

Fridman, S., Sinai,T., and D. Zilberg, D. 2014. Efficacy of garlic based treatments against monogenean parasites infecting the guppy (Poecilia reticulata (Peters)). Veterinary Parasitology 203(1-2), 51-58.

DOI: $10.1016 /$ j.vetpar.2014.02.002

Goddek, S., Delaide, B., Mankasingh, U., Ragnarsdottir, K.V., Jijakli, H., Thorarinsdottir, R. 2015. Challenges of Sustainable and Commercial Aquaponics. Sustainability 7, 4199-4224;

DOI: $\underline{10.3390 / \mathrm{su} 7044199}$

Goddek, S., Joyce, A., Kotzen, B., Dos-Santos, M. 2019. Aquaponics and Global Food Challenges (In Aquaponics Food Production Systems Edited by Goddek, Joyce, Kotzen, Burnell), 3-18.

DOI: $10.1007 / 978-3-030-15943-6$

Gruhlke, M.C.H., Portz, D., Stitz, M., Anwar, A., Schneider, T., Jacob, C., Slusarenko, A. J. 2010. Allicin disrupts the cell's electrochemical potential and induces apoptosis in yeast. Free Radical Biology and Medicine 49(12), 19161924.

DOI: /10.1016/j.freeradbiomed.2010.09.019

Hutson, K. S., Brazenor, A. K., Vaughan, D. B., and TrujilloGonzález, A. 2018. Chapter Three - Monogenean Parasite Cultures: Current Techniques and Recent Advances. In D. Rollinson and J. R. Stothard (Eds.), 99, 61-91. Academic Press.

DOI: 10.1016/bs.apar.2018.01.002

Hyun Kim, J., Fridman, S., Borochov-Neori, H., Sinai, T. and Zilberg, D. 2018. Evaluating the use of garlic (Allium sativum) for the remedy of Cryptocaryon irritans in guppies (Poecilia reticulata). Aquaculture Research 50(2), 431-438. DOI: $10.1111 /$ are.13904

König, B., Junge, R., Bittsanszky, A., Villarroel, M., Komives, T. 2016. On the sustainability of aquaponics. Ecocycles 2(1), 26- 32. DOI: 10.19040/ecocycles.v2i1.50

Lanzotti, V. 2012. Bioactive polar natural compounds from garlic and onion. Phytochemistry Reviews 11(2-3), 179-196. DOI: $\underline{10.1007 / \mathrm{s} 11101-012-9247-3}$

Lu, C., Zhang, H.Y., Ji, J. and Wang, G.X. 2012. In vivo anthelmintic activity of Dryopteris crassirhizoma, Kochia scoparia, and Polygala tenuifolia against Dactylogyrus intermedius (Monogenea) in goldfish (Carassius auratus). Parasitology Research 110(3), 1085-1090.

DOI: $\underline{10.1007 / \mathrm{s} 00436-011-2592-0}$ 
Martins, M.L., Moraes, F.R., Miyazaki, D.M.Y., Brum., C.D. Onaka,E.M., Bozzo, J. and Fenerick-Jr.F.R. 2002. Alternative treatment for Anacanthorus penilabiatus (Monogenea: Dactylogyridae) infection in cultivated pacu Piaractus mesopotamicus (Osteichthyes: Characidae) in Brazil and their haematological effects. Parasite 9, 175-180.

DOI: $10.1051 /$ parasite/2002092175

Militz, T.A.,P.C., Southgate, A., Carton, G. and Hutson, K.S. 2013. Dietary supplementation of garlic (Allium sativum) to prevent monogenean infection in aquaculture. Aquaculture 408, 95-99.

DOI: $\underline{10.1016 / \mathrm{j} . \text { aquaculture.2013.05.027 }}$

Ramudu, K.R, and Dash; G. 2013. A review on herbal drugs against harmfull pathogens in aquaculture. American Journal of Drug Discovery and Development 3(4), 209-219.

DOI: 10.3923 /ajdd.2013.209.219

Paperna, I. 1996. Parasites, infections and diseases fo fishes in Africa. Rome: Food and Agriculture Organization of the United Nations.

Roque, A., Yildiz, H.Y., Carazo, I., and Duncan, N. 2010. Physiological stress responses of sea bass (Dicentrarchus labrax) to hydrogen peroxide (H2O2) exposure. Aquaculture, 304, 1-4.

DOI: $10.1016 / \mathrm{j}$.aquaculture.2010.03.024

Pickering, A.D., Pottinger, T.G., Christie, P., 1982. Recovery of the Brown trout,

Salmo trutta L., from acute handling stress: a time-course study. Journal of Fish Biology 20, 229-244.

DOI: $10.1111 /$ j.1095-8649.1982.tb03923.x

Schelkle, B., Snellgrove, D., and Cable, J., 2013. In vitro and in vivo efficacy of garlic compounds against Gyrodactylus turnbulli infecting the guppy (Poecilia reticulata). Veterinary Parasitology 198(1-2), 96-101.

DOI: $10.1016 /$ j.vetpar.2013.08.027

Siwicki, A.K. and Anderson, D.P. 1993. Immunostimulation in Fish:Measuring the Effects of Stimulants by Serological and Immunological Methods. Nordic Symposium on Fish Immunology, Lysekil, Sweden, 1993

Soares, B.V., Neves L.R., Ferreira, D.O., Oliveira,M.S.B., Chaves, F.C.M., Chagas, E.C., Gonçalves, R.A. and Tavares-Dias, M. 2017. Antiparasitic activity, histopathology and physiology of Colossoma macropomum (tambaqui) exposed to the essential oil of Lippia sidoides (Verbenaceae). Veterinary Parasitology 234: 49-56.

DOI: $10.1016 /$ j.vetpar.2016.12.012

Stoskopf, M. K. 1993. Fish Medicine. London, W. B. Saunders Company, p.882, 1993.
Tavares-Dias, M. 2018. Current knowledge on use of essential oils as alternative treatment against fish parasites. Aquatic Living Resources 31, 13.

DOI: $\underline{10.1051 / \mathrm{alr} / 2018001}$

Trasviña-Moreno, A.G., Ascencio, F., Angulo, C., Hutson, K.S., Avilés-Quevedo, A.R., Inohuye-Rivera, R.B., and Pérez-Urbiola, J.C. 2017. Plant extracts as a natural treatment against the fish ectoparasite Neobenedenia sp. (Monogenea: Capsalidae). Journal of Helminthology (January), 1-9. DOI: $\underline{10.1017 / S 0022149 X 17001122}$

Trujillo-González, A., Constantinoiu, C.C., Rowe R. and Hutson, K.S. 2015. Tracking transparent monogenean parasites on fish from infection to sexual maturity. International Journal of Parasitology: Parasites and Wildlife 4, 316-322.

DOI: $\underline{10.1016 / j . i j p p a w .2015 .06 .002}$

Valladão, G.M.R., Gallani, S.U. and Pilarski, F. 2015. Phytotherapy as an alternative for treating fish disease. Journal of Veterinary Pharmacology and Therapeutics 38(5), 417-428.

DOI: $\underline{10.1111 / j v p .12202}$

Wang, Y., Wu, Z.F., Wang, G.X., Wang, F., Liu, Y.T., Li, F.Y., and Han, J. 2011. In vivo anthelmintic activity of bruceine A and bruceine D from Brucea javanica against Dactylogyrus intermedius (Monogenea) in goldfish (Carassius auratus). Veterinary Parasitology 177(1-2), 127-133.

DOI: $10.1016 /$ j.vetpar.2010.11.040

Wu, Z.F., Zhu, B., Wang, Y., Lu, C., and Wang, G.X. 2011. In vivo evaluation of anthelmintic potential of medicinal plant extracts against Dactylogyrus intermedius (Monogenea) in goldfish (Carassius auratus). Parasitology Research 108(6), 1557-1563.

DOI: $10.1007 / \mathrm{s} 00436-010-2211-5$

Wunderlich, A.C., Guimarães, A.C., and Takeara, R. 2017. Plant-Derived Compounds as an Alternative Treatment Against Parasites in Fish Farming: A Review. Natural Remedies in the Fight against Parasites 246.

DOI: $10.1007 / \mathrm{s} 12088-013-0409-9$

Yildiz, H.Y. and Pulatsu, S. 1999. Evaluation of the Secondary Stress Response in Healthy Nile Tilapia (Oreochromis niloticus L.) after Treatment with a Mixture of Formalin, Malachite Green and Methylene Blue. Aquaculture Research 30, 379-383.

DOI: $10.1046 / \mathrm{j} .1365-2109.1999 .00341 . x$

Yildiz, H.Y., Robaina, L., Pirhonen, J., Mente, E., Domínguez, D., Parisi, G. 2017. Fish Welfare in Aquaponic Systems: Its Relation to Water Quality with an Emphasis on Feed and Faeces-A Review. Water 9(1), 13.

DOI: $10.3390 / \mathrm{w} 9010013$ 
Yildiz, H.Y., Phan, Q.V., Parisi, G., and Sao, M.D. 2019. Antiparasitic activity of garlic (Allium sativum) and onion (Allium сера) juice against crustacean parasite, Lernantropus kroyeri, found on European sea bass (Dicentrarchus labrax). Italian Journal of Animal Science 18(1), 833-837.

DOI: 10.1080/1828051X.2019.1593058

(C) 2020 by the author(s). This article is an open-access article distributed under the terms and conditions of the Creative Commons Attribution (CC-BY) license (http://creativecommons.org/licenses/by/4.0/). 